\title{
The Emotional Labor of Surveillance: Evidence from the Fast Fashion Retail Industry
}

\author{
Madison Van Oort, University of Minnesota, USA
}

\begin{abstract}
This paper explores the impact of digital and biometric surveillance on front-line fast fashion retail workers. The author begins by taking an intersectional approach to worker surveillance, synthesizing sociology of work and feminist surveillance studies. Through ethnography and interviews, the author finds that automated flexible scheduling, a now widely documented phenomenon, helps fine-tune a just-in-time workforce and spurs additional forms of digital control-including biometric scanners and point-of-sale metrics — when combined with the discourse of the 'suspect flexible worker.' While the technologies described exhibit regular limitations, such as failure and vulnerability to sabotage, they nevertheless have the cumulative effect of exacerbating worker insecurity and reinforcing inequality. Amidst the decline of interactive emotional service work in low-wage retail, the author identifies the presence of another kind of affective labor - that of working amidst often invisible, yet pervasive digital monitoring. The author calls this work the emotional labor of surveillance.
\end{abstract}

\section{Introduction}

New technologies and practices collect an unprecedented amount of information about everyday life. Insurance companies, law enforcement, and retailers all aggregate data about health, criminal behavior, and consumer preferences and purchases (Lyon, 2015; Marx, 2016). But as Sarah Brayne writes, "we actually know very little about how big data is used in surveillance activities and to what consequence" (Brayne, 2017: 977). While recent research advances knowledge on how data collection and surveillance impact the lives of white-collar professionals (Ajunwa et al., 2016; Gregg, 2011) and the poor (Eubanks, 2018; Monahan, 2017; Soss et al., 2011; Willse, 2010), there remains as of yet little empirical evidence of how surveillance and data collection shape experiences of low-wage work. Nearly twenty years ago, Robin Leidner celebrated the potential for scholarship on service work to illuminate "ongoing reformulations of academic understandings of work necessarily to keep pace with the transformations in the economy and in the nature of work" (Leidner, 1999: 82). This paper, 
based on eighteen months of ethnographic fieldwork with front-line workers and labor organizers, investigates how the growing ubiquity of digital monitoring and surveillance technologies impacts employees in a service industry increasingly notorious for its precarious employment practices - fast fashion retail.

In what follows, I begin by taking an intersectional approach to studies of worker surveillance, articulating opportunities for sociologists of work to take seriously how digital surveillance shapes feminized and racialized precarious labor, and for surveillance scholars to attend to how big data and biometric monitoring impact the most marginalized sectors of the labor force. I argue, first, that scholars must analyze worker monitoring technologies in dynamic relationship with one another to have a fuller grasp of both their "structural and cultural dimensions" (Monahan, 2017: 192). In my observations, automated flexible scheduling helps fine-tune a just-in-time workforce. In combination with the discourse of the 'suspect flexible worker' who cannot be tracked through analog means alone, automated scheduling spurs additional forms of digital control. While these technologies exhibit regular limitations, including failure and vulnerability to sabotage, they nevertheless have the cumulative effect of exacerbating worker insecurity and reinforcing inequality. Second, amidst the decline of interactive emotional service work in low-wage retail, I note the presence of another kind of affective labor - managing the emotional weight of often invisible, yet increasingly pervasive monitoring and digital surveillance. I conclude by considering the implications of data collection and surveillance for low-wage service work more broadly.

\section{Background}

Sociology of Work and Feminist Surveillance Studies

Scholarship on precarious work describes how jobs in the Global North have become increasingly feminized and insecure, regularly lacking benefits, decent wages, or union 
representation (Butler, 2006; Kalleberg, 2011, 2011; Standing, 2016). Yet much research in this field still lacks a thoroughly intersectional perspective. Activists and scholars Amber Hollibaugh and Margot Weiss argue that "the myth of LGBT affluence renders queer class and race issues invisible or nonexistent [and] allows both the LGBT and labor movements to overlook the rising queer precariat" (Hollibaugh and Weiss, 2015: 19). In the sector of retail in which I worked, fast fashion, many of my coworkers and interviewees were queer, trans, or gender non-conforming, and the majority of my coworkers were women and people of color - far surpassing figures for retail in the US as a whole (62\% and $21 \%$, respectively (Luce et al., 2014). I therefore advance understandings of queer precarity by tracing how evolving tactics of digital monitoring and surveillance shape the lives and life chances of the most vulnerable members of low-wage service sectors such as retail.

Feminist surveillance studies is a useful framework for pursuing such an agenda since it foregrounds "implications of surveillance for disenfranchised bodies" (Dubrofsky and Magnet, 2015). In this view, surveillance technologies are not neutral or objective, but rather emerge out of and regularly reinforce historic inequalities. Simone Browne (Browne, 2010, 2015), for example, traces the legacy of biometric technologies to the trans-Atlantic slave trade, in which black bodies were marked and tracked as a means of capture and control. Ruha Benjamin argues that new technologies are forced onto populations which historically have little room for refusal (Benjamin, 2016). Others have traced these dynamics at welfare offices, for-profit colleges, airport checkpoints, and throughout the criminal justice system (Cottom, 2016; Dubrofsky and Magnet, 2015; Eubanks, 2018; Magnet, 2011). "Rather than rehashing arguments as to whether or not surveillance keeps the United States safe, [feminist surveillance studies] instead take[s] an intersectional critical feminist approach to illuminate what constitutes surveillance, who is 
scrutinized, why, and at what cost” (Dubrofsky and Magnet, 2015: 15). Bringing a feminist surveillance studies to bear on studies of worker monitoring therefore focuses less on whether or not monitoring works - that is, whether or not it increases efficiency or productivity—and instead foregrounds the work employee monitoring does, paying particular attention to how emerging technologies rely on or reinforce inequalities across categories such as, but not limited to, race, gender, sexuality, and class.

Studying digital surveillance is timely, as monitoring technologies have become more affordable and accessible to employers (Ajunwa et al., 2016), but it is also difficult, since monitoring is to a certain extent an expected part of the work contract (Ball, 2010). Electronic performance monitoring also differs from other forms of worker surveillance in that it can record a copious amount of information about worker behavior on a potentially continuous basis (Jeske and Santuzzi, 2015), often without employee knowledge. Ethnographies in a range of low-wage industries indicate that experiences of and responses to digital surveillance shape and are shaped by worker subjectivity. Elliott and Long's investigation of a grocery distribution center finds that heavy “computer control” (Elliott and Long, 2016: 136) in a highly masculinist work environment exacerbates individual employee competition. Likewise, Levy finds long-haul truckers commonly view digital tracking as a threat to their independence, and sometimes smash or otherwise physically damage in-truck tracking devices out of frustration (EC Levy, 2016). In international call centers, surveillance technology disciplines employees' performance of national identity and their ability to take on American accents and dispositions (Poster, 2011: 895). The above studies remain the exception rather than the rule, however. Surprisingly few scholars have traced how the 'wide and deep' reach of big data surveillance—which “includes a broader swath of people and can follow any single individual across a greater range of 
institutional settings" (Brayne, 2017: 979)_operates within a racialized and gendered economic context.

\section{The Case: Big Data, Fast Fashion}

Fast fashion is a particularly rich area for exploring the racialized and gendered contours of low-wage worker surveillance. In rapidly disappearing retail contexts like department stores or branded apparel chains such as Abercrombie and Fitch (Thompson, 2017), front-line workers are expected to engage in some form of interactive, though largely de-skilled service work, pushing sales and coupons onto customers (Gruys, 2012; Ikeler, 2016a; Mears, 2014; Pettinger, 2004; Williams, 2006; Williams and Connell, 2010). Yet as I found, the primary duty sales associates in fast fashion is not to heavily interact with customers, but to instead focus on receiving, organizing and re-organizing a constant and ever-changing flow of stuff. My coworkers coached me into ignoring disgruntled customers in order to focus on more pressing tasks (e.g. making sure clothes were put away on the sales floor); and customer reviews on sites like Yelp regularly bemoan the lack of service. Fast fashion-dominated by global giants like Zara, H\&M, and Forever 21- achieves this distinction in part because it represents the "longawaited realization" of just-in-time production in the apparel industry, "with items produced in small batches and within short lead times" (Caro and Martínez-de-Albéniz, 2015: 238). While technologies like CCTV or barcodes have for several decades allowed retailers to track both employee and consumer behavior (Bowlby, 2001; Harcourt, 2015), the sophistication and speed with which consumer and worker data now becomes integrated into the fast fashion supply chain is unprecedented in the apparel industry. Digital monitoring is thus an increasingly significant component of retail employee control, alongside direct managerial oversight, undercover shoppers, and lateral coworker surveillance (Andrejevic, 2002; Benson, 1986; Ikeler, 2016b). While classic theories of emotional labor are concerned with "the surveillance of our behavior... 
[and the] surveillance of our feelings" (Hochschild, 2003: 229), I am here concerned with the feelings of surveillance.

Solon Barocas and Karen Levy have coined the term "refractive surveillance," to explain how data about one party — such as consumers — can lead to additional surveillance of another party_-such as workers (Barocas and Levy, 2016). Automated scheduling is the most wellknown example of this phenomenon. Along with a just-in-time inventory, fast fashion and other low-wage retailers have harnessed big data to achieve just-in-time retail workforces in which employee schedules parallel shopper traffic. Research indicates that flexible scheduling carries profoundly negative consequences for low-wage hourly workers who have little autonomy over their schedules, more seamlessly transferring the risk of the market onto front-line workers (Clawson and Gerstel, 2014; Lambert, 2008). Employees lack stable hours, and thus stable pay, from week to week, leading to a growth of "involuntary part-time" work (Luce et al., 2014), which may doubly burden those with caregiving duties (Jacobs and Padavic, 2015). Notably, in 2013, when Forever 21 adopted Kronos - a leading automated workforce management platform, which collects information on everything from customer traffic to the weather- "hundreds of full-time workers were notified that they'd be switched to part-time and that their health benefits would be terminated" (Kaplan, 2015: 36). Fast fashion's ability to harness data to achieve justin-time retail has therefore also resulted in unpredictable schedules, rapid turnover, and an almost complete de-skilling of the sales process. As one labor organizer summarized to me: "Because they can pay such dirt prices for the creation of the fabrics, you know, and then sell the clothing so cheap, there's this air of unimportance almost that just infiltrates everything, including the staff." Fast fashion thus generates decidedly "bad jobs" (Kalleberg, 2011; Luce and 
Fujita, 2012), and is in a sense the proletarianization — or further precariatization, perhaps —of retail labor.

Bringing together and advancing sociology of work and feminist surveillance studies, this paper asks, how might automated scheduling, a now well-documented phenomenon, relate to other forms of worker monitoring? Second, how might these technologies exacerbate feelings of insecurity among already marginalized and highly surveilled populations? An ethnographic approach was particularly well-suited for exploring these questions.

\section{Researching Retail}

I conducted fieldwork related to the fast fashion industry for over 18 months, engaging in workplace ethnography at two separate stores in New York City. ${ }^{1}$ Over the course of the summers of 2015 and 2016, I worked as an entry-level sales associate for two major fast fashion retailers, which I call Talia's and Spark, for approximately ten weeks, or 180 paid hours (my fieldwork additionally included several weeks of pre-employment applications and interviewing). Although my period of employment was relatively brief in each location, high turnover is common throughout the industry (Industries at a Glance: Retail Trade: NAICS 44-45, n.d.). ${ }^{2}$ At both sites, the store consistently brought in new hires, and unfamiliar faces, especially among entry-level employees, were the norm. The labor force was highly racialized, and my whiteness almost certainly eased my foray into the field; hiring practices for front-of-house positions regularly privilege people who embody white, middle-class norms and aesthetics (Williams and Connell, 2010).

\footnotetext{
${ }^{1}$ In addition to working at two stores, I applied to at least five others and interviewed for two additional positions. I also regularly volunteered with a retail workers' advocacy group, which helped me situate my experiences in fast fashion within a broader retail landscape.

2 In a survey of 436 retail workers in New York City, the median length of tenure was just one year (Luce and Fujita, 2012).
} 
My university's IRB was particularly concerned with the well-being of my coworkers, and for that reason they stipulated I go covert for this portion of the project. ${ }^{3}$ Outing myself to entry-level employees—especially if I remained undercover to management—could have jeopardized my coworkers' already precarious employment. My fieldnotes consequently focused more on my embodied experiences of the labor process, and less on the intimate details of the people I worked with. To supplement my ethnography, I conducted formal interviews with twenty current and former fast fashion workers, as well as nine labor activists. My sampling frame included people who had worked in fast fashion within the past two years. I recruited most respondents online through Craigslist and Twitter; three interviewees I connected with by word of mouth. The majority of respondents had been entry-level sales associates, cashiers, or stock people, while two also worked as visual merchandisers; one had risen the ranks into the human resources department. Twelve interview respondents were located in New York City, while seven lived in other cities throughout the US and one in Canada. Although most of my observational data speak to New York City context, I was not surprised to find that what I heard from other cities was similar to New York. Additionally, while companies based outside the US (such as Zara, H\&M, and Uniqlo) adhere to different labor laws in their home countries than those based domestically (such as Forever 21), my findings indicate that entry-level working conditions across different fast fashion companies are more similar than different. ${ }^{4}$ The semistructured interviews lasted around one hour, covering life histories and work experiences; respondents were given a $\$ 20$ gift card reimbursement. All interviews were digitally recorded, transcribed, and coded using the qualitative analysis software Atlas.ti.

\footnotetext{
${ }^{3}$ Once I agreed to this stipulation, my IRB officially approved the study.

${ }^{4}$ An interview with an executive direction of a retail labor workers' center confirms this finding. "If you stripped away the name of the company and you listened to two different workers talk...you wouldn't know who's talking about who."
} 


\section{Findings}

As I anticipated, the constant vacillation of worker schedules infused workplace relations. My coworkers chugged coffee and energy drinks to endure 6am shifts, while others frantically arranged childcare from their phones in the break room. Even the most on-top-of-it associates could not keep their schedules straight. As my own manager reviewed my new-hire paperwork with me, she shouted at a young woman walking by, "Hey! Do you still work here?” I was shocked that even those in power had difficulty keeping track of employees. Other managers regularly forgot when I had clocked in, and my coworkers taught me to advocate for myself when my break was due or my shift over.

As I would come to find, computer-generated flexibility undergirded the idea of the 'suspect worker', who came and went too often to be kept track of 'the old-fashioned way,' meaning through human oversight alone. As I detail below, incessant employee turnover throughout the day and fluctuating weekly schedules justified additional forms of automated control, compounding anxiety and insecurity among front-line workers. This often occurred as soon as employees clocked in.

\section{In Touch and On Time: Biometric Fingerprint Scanners as Time Management}

Automated schedulers re-shape worker schedules as well as the mechanisms through which employees account for their time worked. Kronos, a leading workforce management company, sells biometric fingerprint technology as a companion to its automated scheduling software, calling it "the first time clock built for today's modern workforce" with "rock solid reliability" (Kronos, 2017). In this case, a "modern workforce," indicates one that is everchanging and requiring digital management, while "reliability" is framed as protecting corporate interests. By scanning employee fingerprints, biometric clocks purport to provide employers with more accurate timekeeping, cutting down on workers' attempts to receive wages for time not 
worked. Retailers refer to such practices as "time stealing"; "buddy punching" indicates coworkers clocking in or out for one another. These frameworks uphold an the image of the potential worker criminal, while ignoring much more widely documented instances of wage theft, in which employers avoid fully compensating their employees (Halpin, 2015; Traub, n.d.). ${ }^{5}$ Both Talia's and Spark required employees to clock in by scanning their fingerprint at the beginning and end of each shift, as well as for lunch breaks. Any deviation from this procedure left one prone to "disciplinary action" according to the Talia's handbook, and indeed, by providing an extensive list of possible deviations, the handbook assumed workers could and would attempt subterfuge

Despite their supposed reliability, biometric technology regularly malfunctions (Browne, 2015; Magnet, 2011). During one of my first shifts at Spark, my manager, Emily, and I encountered numerous difficulties trying to register my information in the scanning system. Two biometric scanners hung on a wall in between the seating area and the staff lockers in the breakroom. After my manager punched a few buttons, the machine instructed me to place my finger on the scanning pad. "No finger detected," the machine read. "Try again," Emily told me, wiping the pad with a tissue. Still no finger detected. "Maybe try a different finger," she advised. This time I used a different finger, but still, no finger detected. "Let's try this machine," she said, entering her employee id number and scanning her own finger on the machine next to us. I placed my finger on the second machine, attempting to apply more pressure, to no avail. "Put,

\footnotetext{
${ }^{5}$ Other common examples of wage theft include requiring workers to continue working even after they clock out, refusing workers their legally required breaks, and requiring workers to stay after clocking out to submit to bag checks before leaving to prevent theft. During my fieldwork, managers regularly forgot how long I was scheduled for that day, and consequently forgot to grant me my legally required breaks. And at both Talia's and Spark, workers waited, sometimes several minutes, to have their bag checks after clocking out. One worker, Susanna, told me: "When you're ready to go home the manager isn't ready and you have to wait for them to let you out. They have to like check your bag. So that's annoying because you clock out and then you don't get paid for the time you have to stay after."
} 
like, your whole finger on there," she said. Alas, still no finger detected. "Go wash your hands," she quipped, annoyed but not overtly frustrated, as if she had encountered similar difficulties before. I scanned my finger once more after thoroughly washing my hands. The machine then displayed the following message: "Error, no employee scheduled." To my confusion, but also relief, Emily told me, "Ok that actually means it worked. You're in the system now. But since your schedule hasn't yet been put in, it says that error. But it does log when you clock in and out, so just do that like usual and we'll be able to pay you that way." After all that trouble, the error was apparently derived from my own sweat-induced anxiety (one might say the sweat was itself a haptic outcome of engaging with the scanner). I trusted that the machine was properly counting my hours all that week, even as it beeped loudly each time I clocked in or out. Biometric fingerprint scanners are also prone to "demographic failures," regularly failing to scan prints of elderly people, Asian women, people who work in manual or clerical industries, or people whose fingers are too large (Browne 2015; Magnet 2011).

At Talia's, the scanners malfunctioned weekly. Workers waited in long lines at shift change, hastily scrawling their hours in a notebook by pen or pencil. We hoped managers would input our time correctly, if at all. My interviewees shared similar experiences. One said, "I remember a lot of times [the scanner] didn't work. Sometimes it didn't, sometimes it did. So you'd have to put it in manually." I also had the following exchange with Susanna, who had worked at multiple fast fashion locations along the East Coast.

Susanna: It was annoying, sometimes [the fingerprint scanner] didn't work.

M: What would you have to do when it didn't work?

Susanna: You'd have to let a manager know, and then they'd put in the time for you. And that was really annoying because, like, everything's really hectic, everything's really busy. You'd have to like, hound them for it.

M: Did that ever happen to you? 
Susanna: Yeah, a lot of times. When I first started working there, I didn't get paid for like weeks of work.

In these examples, the ease and efficiency of biometric scanners almost exclusively operated in employers' interests, amplified worker anxiety, and made them prone to wage theft.

Like other technologies, biometric scanners remained vulnerable to worker sabotage.

Jesse shared: "It was hard to have someone sign in and out for you. But I know we would definitely [tell each other], just don't sign in, just say the system was down and just put your time on the paper. We'd do that for each other every now and then. Especially when we were late or things like that." Another sales associate, Vanessa, told me management at her store had become stricter about where people could clock in "because they don't want people to steal hours." When I asked if many people did that, she laughed and said yes; "I was one of them." While some might categorize Vanessa and her co-workers' behavior as deviant, she quite clearly articulated it as a collective response to the stresses of automated flexible scheduling. Not only would she partake in minor subversion, such as going to the bathroom before clocking out, but she and her coworkers began arriving as much half an hour early, clocking in and then hanging out in the breakroom. She said, “They were sending us home early because they didn't have enough work [for us] to do... So it was like...if anything, we just clock in, not clock out for 30 minutes." My intention here is not to diminish the seriousness of wage theft, nor the ways that employees can and have leveraged automated record keeping to dispute wage theft (Dombrowski et al., 2017), but to instead document the conflict inherent these technologies (Thompson, 1967), or how, in surveillance theorist Kirstie Ball's words, "strategies of resistance occur at the boundary of the body and surveillance and at an intersubjective level” (Ball, 2005: 104). In my observations, employees regularly engaged in daily attempts to take back time for themselves, for instance by absconding to the fitting room — one of the few spaces free from CCTV's threatening gaze - to 
send texts, take selfies, or simply admire themselves in the mirror. Compared to the masculinist interventions that Levy notes in her study of truck drivers, who would go so far as to smash their in-truck performance monitors (EC Levy, 2016), the tactics of resistance to digital surveillance I encountered were less overt, indicative of more feminized and precarious subject positions.

These tensions reflect increasingly widespread debates on this largely unregulated form of surveillance. Current class-action lawsuits against hotel and grocery chains in Illinois - one of the few states with regulation on biometric data collection-claim the employers failed to acquire written consent for the collection of biometric data and did not disclose how long such data would be stored nor how it would be destroyed. "Unlike, say, a stolen company ID, which can be replaced, individuals can't order up a new body part, raising concerns about what could happen if scans of their fingertips' arches, loops, and whorls fell into the wrong hands" (Yerak, 2017). Despite the growing ubiquity of fingerprint scanning in everyday life-fingerprints commonly unlock personal cell phones, for example_-among retail workers, biometric fingerprint scanners reinforced the idea that workers were always already potential criminals. Engaging with biometric systems cues bodily reactions (hearts racing, palms sweating), while their failure exacerbates anxieties of an already hectic environment.

Even after clocking in, employees continue to be monitored as they move throughout the store. In my fieldwork, this happened most extensively at the point of sale.

Point-of-Sale Surveillance: "You know we track that right?"

Working at the cash register is one of the most exasperating duties for an entry-level fast fashion retail employee. Lines grow long, sensors beep at multiple registers simultaneously, and music blares, making it difficult to think straight, let alone check out customers quickly, efficiently, and with a pleasant demeanor. As my interviewees shared: 
Rachel: It was crazy.... I had never been on a register before. There's lines down and around the corner. People usually buy like a hundred things at once. So you check the credit card, check the IDs, take the sensor off, you know, talk to them, also like, counting the register... It was a lot of pressure and it just made me really anxious.

$* * *$

Zarina: [The cash register] was a little more stressful because the line-ups would be constant. Especially during the holidays or when we would have collaborations with designers. It would just be a lot to keep going. Deal with one customer, they make a $\$ 300$ purchase, then deal with another customer.

Most people working at the register were well aware of the multiple security cameras observing their every move, but fewer with whom I spoke understood the extent to which their interactions were followed digitally. At the beginning of each shift, workers logged into the register's computer system, and with this information, analytic software could then generate performance reports, collecting behavior at the aggregate level, while also identifying individual transactions, as illustrated in the figure below.

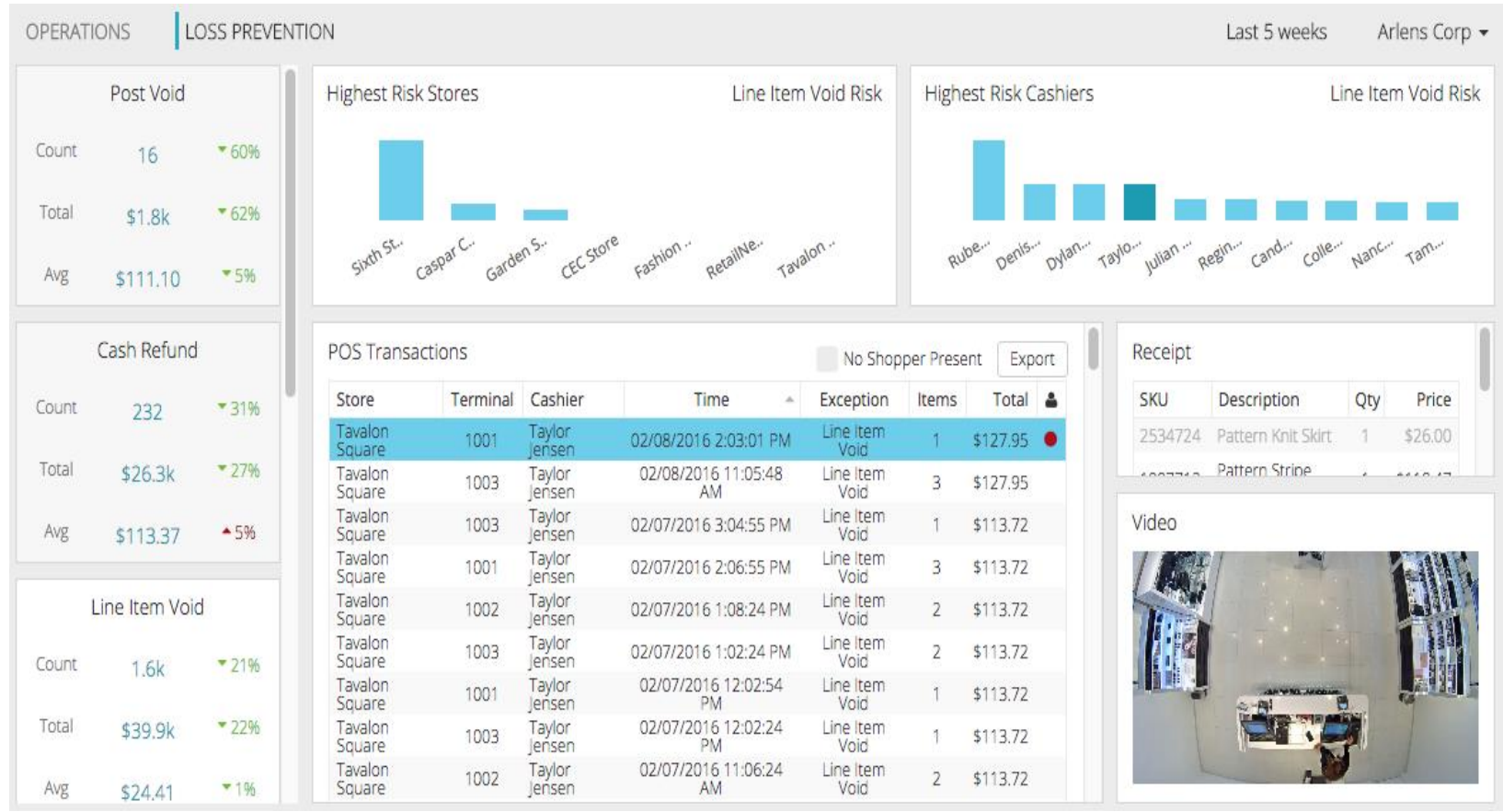

Invoking Foucaultian normalization (Foucault, 1995), the retail industry has dubbed this approach "exception-based reporting," flagging workers who, for instance, might be taking too 
long to complete transactions or have logged a suspiciously high number of customer returns. According to the company RetailNext, which produces the software illustrated here, this image shows an "alert of a high-risk transaction that took place without a customer being present [highlighted in the center of the image in blue]. One click on the transaction brings up not only the receipt [middle right], but the corresponding video as well [bottom right]." The top two segments aggregate information at the company and store level, pinpointing both "highest risk stores" (top center) and "highest risk cashiers" (top right). This platform is sold to retailers not only on its accuracy, but its efficiency. According to its website, "Just like that - what used to take all morning now takes a couple of clicks... It's not only easier for the LP [Loss Prevention] professional, but it allows increasingly tight personnel resources and budgets to be allocated more efficiently, more effectively." (Hartjen, n.d.). Such software automates retail management, combining new and previously distinct sets of information to identify company-level trends as well as mark individual employees.

Often, when I would ask my interviewees about how their cashier performance was tracked, they immediately noted the presence of security cameras. Only upon further pressing did they reflect on the role of automated surveillance. Exchanges like the one below with Elijah were common.

M: Would you log into the register with your employee card or something? Elijah: No, you have a pin and your employee number so a six or seven digit code, it might be up to seven now. Seven digit code, type in a pin that you set.

M: And why did you do that? Do you know?

Elijah: Why did we do that versus [what]? That's just what the system was.

M: Do you know why they had people log in?

Elijah: I guess so they can say, if you make a mistake it's on you. Or if a customer got double charged, it's on you. 
Elijah's comment_- "that's just what the system was" reveals the extent to which various forms of surveillance have become a normalized aspect of work and life in the $21^{\text {st }}$ century, especially for people of color and in cities like New York (Lippert and Wood, 2012). While Elijah understands this monitoring as an everyday part of the job, he simultaneously concludes that its ultimate objective is to place additional burden on employees; as he emphasized, "It's on you."

While often invisible, digital point-of-sale monitoring can have detrimental impacts on low wage workers. During my cash register training at Talia's, a current employee told me and my fellow trainees of a button to correct transactions, which we could use as often as necessary. Our floor manager spun to her, blurting, "You know we track that, right?" The employee's eyes grew wide in distress. In another case, one of my interviewees, Jesse, had worked at Talia's in Los Angeles. He told me that he once put five dollars - half an hour's wages - from his own pocket into the register when his drawer came up short; being reprimanded for previous mistakes, he said, had been "terrifying." Similarly, Elijah told me: “The rule with them is, if you're under anything more than $\$ 75$ dollars, it's automatic termination. If you have someone under $\$ 40$ it might not be their fault. It's an honest, slight mistake. But they'd still fire them because they'd see it as they'd have the potential to do it again." These examples from Jesse and Elijah illustrate how worker monitoring can increase workers' sense of insecurity in a context of big data surveillance: while they might not be aware of exactly how they are being monitored, they know being even a few dollars off is a risk they can't afford to take, especially when they are both trying to pay their way through school and their labor power is easily replaceable.

While surveillance proliferates at the point of sale, again, so too do employee responses. Jesse shares, "Learning all the codes [for clothes] was very important. You know I was really fast at getting customers in and out, in and out. And if I made a small mistake I would just, like, 
not do anything about it, and just get it done. That was really important in the holiday season, to keep our lines down." Maintaining the flow of customers was essential in this setting, since long lines tend to stoke customer dissatisfaction, which front-line workers must bear the brunt of. When I asked Jesse to provide a specific example of tricks he used to help keep the lines flowing, he expressed reliance on what Gary Marx (Marx, 2003) calls "distorting moves" and what Finn Brunton and Martha Nissenbaum (Brunton and Nissenbaum, 2011) have more recently dubbed "obfuscation" by entering technically valid, but inaccurate, information at the cash register: "A lot of times the clothes wouldn't scan in, so you'd have to type in the code. I'd type in the code and, you know, it would not really give me anything, or I'll search and I'll pick and choose. Like oh I'll just pick this shirt 'cause it has the same design on it, you know?" In this way, the code he punched to ring up a particular garment was incorrect, but it was close enough to allow him to keep lines moving. Jesse was additionally required to solicit personal email address from customers, which he sometimes avoided by entering his own email address instead: "The funny thing is I've put in my email a thousand times." While I laughed along, this anecdote highlights an important dynamic. Distorting moves here operated as a form of labor, less resistance than a survival mechanism in a sped-up, hyper-surveilled, and under-compensated line of work.

At the cash register, fast-paced work is monitored intermittently by mangers who count the drawers, as well as continuously and visibly by video cameras, and continuously but invisibly by digital point-of-sale monitoring. Most employees had spent little time reflecting on this digital surveillance, but when they did, they appeared startled or resigned to the reality that it made their work more stressful and more unstable. What at first blush appears resistant is in fact a form of 
coping, invoking humor to pad the very serious consequences that could result if their

performance is identified as an exception to be investigated.

\section{Discussion and Conclusion: How Data Fashion Precarity}

This paper advances both critical labor studies and feminist surveillance studies by investigating the effects of digital surveillance on low-wage workers with high proportions of women workers, queer and/or gender non-normative workers and workers of color. My findings indicate that the growth of software used to automate employee schedules not only creates new norms of short shifts and fluctuating employee calendars, but also encourages employers to engage additional methods of automated control. In settings where the employee base changes as quickly as the store inventory, the propensity to treat workers like potential criminals becomes amplified. Biometric fingerprinting purports to provide objective time keeping for today's "modern" (i.e. flexible) workforce by preventing time theft and buddy punching, while software that tracks and aggregates cash register transactions encourages employers to quickly pinpoint "exceptions" within a large pool of cashiers, exerting more pressure on an already stressful task. These findings suggest that researchers should take a more holistic approach technology in the workplace, investigating how distinct forms of tracking are not simply additive but exist in particular relation with one another.

While framed by the surveillance industry as neutral and objective, these tools have the cumulative effect of intensifying anxiety and insecurity among front-line employees. Biometric fingerprinting cues physical and emotional responses, while its regular malfunctioning causes workers to worry about the accuracy of their paychecks. Point-of-sale monitoring amplifies and already stressful task, and remind workers that they—not the company—are to shoulder the burden of any mistakes. As the circulation of data lubricates a transition to just-in-time retail, the labor process itself has shifted. Although workers rarely engage in skilled or even semi-skilled 
selling, a less obvious form of emotional labor helps keep the store running. Amid life-jumbling automated schedulers, sweat-inducing biometric scanners, and anxiety-provoking point-of-sale monitoring, front-line workers must resist becoming overwhelmed, keeping clothes and customers moving. This work can be understood as the emotional labor of surveillance.

In focusing on the fast fashion retail sector, I witnessed how workplace surveillance perpetuates inequality and coheres along lines of gender, race, and sexuality. Emerging scholarship highlights how privacy operates differently for the underclasses (Adler-Bell, 2018; Eubanks, 2018). Women of color, indigenous women, and gender or sexual deviants have rarely been afforded individual privacy by the state (Mogul et al., 2012; Smith, 2015). Invasions of privacy or unregulated data sharing can also have amplified consequences for members of marginalized groups, leading to arrest, deportation, or even death (as in the case of stop and frisk). Biometric data - whether fingerprints or facial scans, not discussed here but budding in the retail context (Frey, 2016) — could potentially be shared with law enforcement, and targeting someone for employee theft could increase potential points of contact between them and police. Future research should thus follow the data to see the extent to which worker information can and is shared across disciplinary contexts. Other research could compare the contours of the emotional labors of surveillance across industries and work populations. For instance, how might the anxieties of employee wellness programs in white collar workplaces compare to that of biometric fingerprint scanning of low-wage workers? Considering possible solutions, what might be potential or unexpected points of overlap between such disparate groups? How might critiquing the variegated experiences of worker surveillance help forward a critical data praxis? 


\section{References}

Adler-Bell S (2018) Privacy for Whom? In: The New Inquiry. Available at: https://thenewinquiry.com/privacy-for-whom/ (accessed 23 February 2018).

Ajunwa I, Crawford K and Schultz J (2016) Limitless Worker Surveillance. California Law Review 105(3).

Andrejevic M (2002) The work of watching one another: Lateral surveillance, risk, and governance. Surveillance \& Society 2(4).

Ball K (2005) Organization, surveillance and the body: Towards a politics of resistance. Organization 12(1): 89-108.

Ball K (2010) Workplace surveillance: an overview. Labor History 51(1): 87-106. DOI: $10.1080 / 00236561003654776$.

Barocas S and Levy K (2016) What Customer Data Collection Could Mean for Workers. Available at: https://hbr.org/2016/08/the-unintended-consequence-of-customer-datacollection (accessed 18 January 2017).

Benjamin R (2016) Informed refusal: Toward a justice-based bioethics. Science, Technology, \& Human Values 41(6): 967-990.

Benson SP (1986) Counter cultures: saleswomen, managers, and customers in American department stores, 1890-1940. Urbana: University of Illinois Press.

Bowlby R (2001) Carried away: The invention of modern shopping. Columbia University Press.

Brayne S (2017) Big data surveillance: The case of policing. American Sociological Review 82(5): 977-1008.

Browne S (2010) Digital epidermalization: race, identity and biometrics. Critical Sociology 36(1): 131-150.

Browne S (2015) Dark matters: on the surveillance of blackness. Durham, NC: Duke University Press.

Brunton F and Nissenbaum H (2011) Vernacular resistance to data collection and analysis: A political theory of obfuscation. First Monday 16(5). Available at:

http://firstmonday.org/ojs/index.php/fm/article/view/3493 (accessed 29 January 2017).

Butler J (2006) Precarious Life: The Powers of Mourning and Violence. Brooklyn, NY: Verso.

Caro F and Martínez-de-Albéniz V (2015) Fast Fashion: Business Model Overview and Research Opportunities. In: Agrawal N and Smith SA (eds) Retail Supply Chain Management. International Series in Operations Research \& Management Science 223. Springer US, pp. 237-264. DOI: 10.1007/978-1-4899-7562-1_9. 
Clawson D and Gerstel N (2014) Unequal time: Gender, class, and family in employment schedules. Russell Sage Foundation.

Cottom TM (2016) Black CyberFeminism: Intersectionality, Institutions and Digital Sociology. Digital Sociologies.

Dombrowski L, Alvarado Garcia A and Despard J (2017) Low-Wage Precarious Workers' Sociotechnical Practices Working Towards Addressing Wage Theft. In: Proceedings of the 2017 CHI Conference on Human Factors in Computing Systems, New York, NY, USA, 2017, pp. 4585-4598. CHI '17. ACM. DOI: 10.1145/3025453.3025633.

Dubrofsky RE and Magnet S (2015) Feminist surveillance studies. Durham, NC: Duke University Press.

EC Levy K (2016) Digital surveillance in the hypermasculine workplace. Feminist media studies 16(2): 361-365.

Elliott CS and Long G (2016) Manufacturing rate busters: computer control and social relations in the labour process. Work, employment and society 30(1): 135-151.

Eubanks V (2018) Automating Inequality: How High-Tech Tools Profile, Police, and Punish the Poor. New York, NY: St. Martin's Press.

Foucault M (1995) Discipline and punish: the birth of the prison. New York: Vintage Books.

Frey C (2016) Revealed: how facial recognition has invaded shops - and your privacy. Available at: https://www.theguardian.com/cities/2016/mar/03/revealed-facial-recognitionsoftware-infiltrating-cities-saks-toronto (accessed 31 August 2017).

Gregg M (2011) Work’s intimacy. Cambridge, UK; Malden, MA: Polity.

Gruys K (2012) Does This Make Me Look Fat? Aesthetic Labor and Fat Talk as Emotional Labor in a Women's Plus-Size Clothing Store. Social Problems 59(4): 481-500. DOI: 10.1525/sp.2012.59.4.481.

Halpin BW (2015) Subject to Change Without Notice: Mock Schedules and Flexible Employment in the United States. Social Problems 62(3): 419-438. DOI: 10.1093/socpro/spv008.

Harcourt BE (2015) Exposed: desire and disobedience in the digital age. Cambridge.

Hartjen R (n.d.) LP Made Easy (-ier): POS Exception Reporting with Integrated Video | RetailNext. Available at: http://retailnext.net/en/blog/lp-made-easy-ier-pos-exceptionreporting-with-integrated-video/ (accessed 3 February 2017).

Hochschild AR (2003) The managed heart: Commercialization of human feeling. Berkeley: Univ of California Press. 
Hollibaugh A and Weiss M (2015) Queer precarity and the myth of gay affluence. New Labor Forum 24: 18-27.

Ikeler P (2016a) Deskilling emotional labour: evidence from department store retail. Work, Employment \& Society 30(6): 966-983.

Ikeler P (2016b) Hard Sell: Work and Resistance in Retail Chains. Ithaca, New York: Cornell University Press.

Industries at a Glance: Retail Trade: NAICS 44-45 (n.d.). Available at: https://www.bls.gov/iag/tgs/iag44-45.htm (accessed 17 July 2017).

Jacobs AW and Padavic I (2015) Hours, Scheduling and Flexibility for Women in the US LowWage Labour Force. Gender, Work \& Organization 22(1): 67-86. DOI:

10.1111/gwao.12069.

Jeske D and Santuzzi AM (2015) Monitoring what and how: psychological implications of electronic performance monitoring. New Technology, Work and Employment 30(1): 6278. DOI: $10.1111 /$ ntwe.12039.

Kalleberg AL (2011) Good jobs, bad jobs: the rise of polarized and precarious employment systems in the United States, 1970s to 2000s. New York: Russell Sage Foundation.

Kaplan E (2015) The spy who fired me: The human costs of workplace monitoring. Harper's: $31-40$.

Kronos (2017) Kronos InTouch. Available at: https://www.kronos.com/products/kronos-intouch (accessed 3 February 2017).

Lambert SJ (2008) Passing the buck: Labor flexibility practices that transfer risk onto hourly workers. Human Relations 61(9): 1203-1227.

Leidner R (1999) Emotional labor in service work. The annals of the American academy of political and social science 561(1): 81-95.

Lippert RK and Wood DM (2012) The New Urban Surveillance: Technology, Mobility, and Diversity in 21st Century Cities. Surveillance \& Society 9(3): 257-262.

Luce S and Fujita N (2012) Discounted Jobs: How Retailers Sell Workers Short. Available at: http://retailactionproject.org/2012/01/discounted-jobs-how-retailers-sell-workers-shortexecutive-summary/ (accessed 16 July 2017).

Luce S, Hammad S and Sipe D (2014) Short Shifted. Retail Action Project. Available at: http://retailactionproject.org/wpcontent/uploads/2014/09/ShortShifted_report_FINAL.pdf.

Lyon D (2015) Surveillance after Snowden. Malden, MA: John Wiley \& Sons. 
Magnet S (2011) When biometrics fail: gender, race, and the technology of identity. Durham: Duke University Press.

Marx GT (2003) A tack in the shoe: Neutralizing and resisting the new surveillance. Journal of Social Issues 59(2): 369-390.

Marx GT (2016) Windows into the soul: Surveillance and society in an age of high technology. University of Chicago Press.

Mears A (2014) Aesthetic labor for the sociologies of work, gender, and beauty. Sociology Compass 8(12): 1330-1343.

Mogul JL, Ritchie AJ and Whitlock K (2012) Queer (In)Justice: The Criminalization of LGBT People in the United States. Boston, Mass; Enfield: Beacon Press.

Monahan T (2017) Regulating belonging: surveillance, inequality, and the cultural production of abjection. Journal of Cultural Economy 10(2): 191-206.

Pettinger L (2004) Brand culture and branded workers: Service work and aesthetic labour in fashion retail. Consumption Markets \& Culture 7(2): 165-184.

Poster WR (2011) Emotion detectors, answering machines, and e-unions: Multi-surveillances in the global interactive service industry. American Behavioral Scientist 55(7): 868-901.

Queer Survival Economies (2015) Invisible Lives, Targeted Bodies: Impacts of Economic Injustice on Vulnerable LGBTQ Communities. Available at: http://queersurvivaleconomies.com/our-work/conference/ (accessed 20 March 2018).

Smith A (2015) Not Seeing: State Surveillance, Settler Colonialism, and Gender Violence. In: Feminist Surveillance Studies. Durham, NC: Duke University Press.

Soss J, Fording RC and Schram S (2011) Disciplining the poor: Neoliberal paternalism and the persistent power of race. Chicago: University of Chicago Press.

Standing G (2016) The precariat: The new dangerous class. Bloomsbury Publishing.

Thompson D (2017) The Great Retail Apocalypse of 2017 - The Atlantic. Available at: https://www.theatlantic.com/business/archive/2017/04/retail-meltdown-of-2017/522384/ (accessed 17 May 2017).

Thompson EP (1967) Time, work-discipline, and industrial capitalism. Past \& Present (38): 5697.

Traub A (n.d.) The Steal: The Urgent Need to Combat Wage Theft in Retail | Demos. Available at: http://www.demos.org/publication/steal-urgent-need-combat-wage-theft-retail (accessed 23 June 2017). 
Williams CL (2006) Inside toyland: working, shopping, and social inequality. Berkeley, Calif.: University of California Press.

Williams CL and Connell C (2010) "Looking good and sounding right" aesthetic labor and social inequality in the retail industry. Work and Occupations 37(3): 349-377.

Willse C (2010) Neo-liberal biopolitics and the invention of chronic homelessness. Economy and Society 39(2): 155-184.

Yerak B (2017) Mariano's, Kimpton Hotels sued over alleged collection of biometric data: 'It's something very personal'. chicagotribune.com, 21 July. Available at: http://www.chicagotribune.com/business/ct-employers-biometrics-lawsuits-0723-biz20170720-story.html. 